\title{
Estado de exceção e emergência sanitária: Giorgio Agamben sobre a pandemia por coronavírus
}

\author{
Alan Barbosa Buchard ${ }^{1}$
}

1 Doutorando pelo Programa de pós-graudação em Lógica e Metafísica (PPGLM). Área: Filosofia da ação E-mail: buchardalan@hotmail.com Orcid: http://orcid.org/0000-0001-5189-1665

RESUMO: O presente artigo possui como tema a perspectiva do filósofo italiano Giorgio Agamben (1942-) sobre a atual emergência sanitária por Sars-Cov-2, a pandemia pelo novo coronavírus. A pesquisa circunscreve a problemática levantada pelo filósofo acerca das consequências ético-políticas dos estados de exceção decretados pelos governos democráticos contemporâneos em resposta à crise sanitária por covid-19. O artigo tem por objetivo analisar e explicitar as teses defendidas por Giorgio Agamben em um conjunto de textos publicados em seu blog particular - Una Voce - e disponível na bomepage da editora italiana Quodlibet. Uma tradução para o português está disponível em e-book no site da editora Boitempo, intitulada Reflexões sobre a peste: ensaios em tempos de pandemia. A metodologia de análise retoma as premissas e teses da filosofia política desenvolvidas por Giorgio Agamben em obras anteriores, tais como Homo Sacer I: poder soberano e a vida nua (1995), Homo sacer II, 1: o estado de exceção (2003) e em Signatura Rerum: sobre o método (2019). O resultado obtido consiste na apresentação do percurso filosófico das análises de Giorgio Agamben durante a fase inicial da pandemia, na qual o autor não parece estar preocupado em fazer diagnósticos do quadro epidêmico, menos ainda investigar as causas e os efeitos médicos do CoV-2, como fazem os virologistas e infectologistas. A leitura e comentário dos textos selecionados permitem concluir que, para o autor, a atual pandemia serve de oportunidade para a normalização do paradigma da exceção como forma de governo nas democracias contemporâneas e de ocasião para a realização plena do regime da biopolitica

Palavras-chave: Agamben, pandemia, estado de exceção.

ABSTRACT: This article has as its theme the perspective of the philosopher Giorgio Agamben (1942-) on the current health emergency by Sars-Cov-2, the pandemic for the new coronavirus. The research circumscribes the problem raised by the philosopher about the ethical-political consequences of states of exception enacted by contemporary democratic governments in response to the health crisis by covid-19. The article aims to analyze and explain the theses defended by Giorgio Agamben in a set of texts published on his private blog - Una Voce - and available on the homepage of the Italian publisher Quodlibet. A Portuguese translation is available in an e-book on the website of the publisher Boitempo, entitled Reflections on the plague: essays in times of pandemic. The analysis methodology takes up the premises and theses of political philosophy developed by Giorgio Agamben in previous works, such as Homo Sacer I: sovereign power and naked life (1995), Homo sacer II, 1: the state of exception (2003) and in Signatura Rerum: about the method (2008). The result obtained is the presentation of the philosophical path of Giorgio Agamben's analyzes during the initial phase of the pandemic. The test result consists of presenting the philosophical tracking of Giorgio Agamben's analyzes during an initial phase of the pandemic, in which the author does not seem interested in making diagnoses of the epidemic, much less investigating how the medical causes and effects of CoV2 , how do virologists and infectologists. Reading and commenting on the selected texts allows us to conclude that, for the author, the current pandemic serves as an opportunity for the normalization of the exception paradigm as a form of government in contemporary democracies and as an occasion for the full realization of the biopolitics regime. 
Keywords: Agamben, pandemic, exception state

\section{INTRODUÇÃO}

Em 31 de dezembro de 2019 a China informa à Organização Mundial da Saúde (OMS) sobre "pneumonia misteriosa em Wuhan" - cidade da província de Hubei, região central do país ${ }^{1}$. É a primeira vez em que são registradas ocorrências de seres humanos infectados por uma nova forma de vírus. Um dia após o informe à $O M S$, em 1 de janeiro de 2020, o governo chinês fecha o mercado popular da cidade de Wuhan em meio à suspeita de que animais teriam detonado o contágio. Neste mesmo dia, é divulgado o tipo de genoma do vírus: é um coronavírus².

Em 11 de fevereiro de 2020, contando com o registro de mais de 1.200 mortes, a OMS anuncia o nome oficial do novo coronavírus: Sars-CoV-2 (Severe acute respiratory syndrome coronavirus 2), isto é, sindrome respiratória aguda grave por coronavírus 2. A infecção desencadeada por ele é designada pela fórmula covid-19: co (“corona"), vi ("vírus"), d (disease, termo inglês para "doença"), 19 (referência ao ano de sua descoberta, 2019).

Em 11 de março, um mês após o primeiro registro da contaminação por Sars-CoV-2 - ou, na forma abreviada, CoV-2 - o Diretor-geral da OMS, Dr. Tedros Adhamon Ghebreyesus, anunciou a Covid-19 como pandemia global. Os números dos óbitos registrados chegavam então a mais de 4.500 mortes. Simultaneamente às declarações da OMS, os países da Europa, que já vinham adotando medidas de emergência no combate a propagação do vírus, endureceram as estratégias de enfrentamento. Dentre elas, aplicava-se medidas de isolamento social (quarentena), o fechamento completo dos estabelecimentos comerciais e interdição de locais públicos (lockdown), a interrupção das atividades escolares e universitárias, a suspensão de eventos culturais, a proibição de aglomeração pública, restrição da mobilidade, anúncios de pacotes emergenciais de recuperação econômica, etc.

Até a data de início de redação deste trabalho - segunda semana de abril -, Agamben havia publicado um conjunto de seis textos. Em ordem cronológica, são eles: 1) A invenção de uma epidemia (publicado em 26 de fevereiro de 2020); 2) Contágio (de 11 de março de 2020); 3) Esclarecimentos (de 17 de março de 2020); 4) Reflexões sobre a peste (de 27 de março de 2020); 5) Distanciamento social (de 6 de abril de 2020); 6) Uma pergunta (de 14 de abril de 2020$)^{3}$.

Como recorte epistemológico, o artigo propõe analisar e comentar os três primeiros textos publicados pelo filósofo. Termos técnicos do léxico agambeniano tais como "estado de exceção", "biopolítica", "vida nua" e "paradigma” servirão como chave-de-leitura na explicitação do aparato conceitual político

\footnotetext{
1 Todas as referências às datas da pandemia foram retiradas do vídeo Cronologia Covid-19: de pneumonia misteriosa à pandemia, da BBC News Brasil, publicado em seu próprio canal YouTube no dia 20 de abril de 2020. Cf. https://www.youtube.com/watch?v=5NJaUlHtwOo\&t=267s. Acessado em 16/04/2020.

20 coronavírus é um grupo de vírus comum entre os animais. Em casos raros, ele é o que os cientistas chamam de "zoonótico", o que significa que pode ser transmitido de animais para seres humanos. 0 termo zoonoses designa o conjunto de doenças humanas causadas por patógenos que normalmente infectam animais. Cf. http://www.medicinanet.com.br/conteudos/acp-medicine/6179/zoonoses_virais.htm. Acessado em 16/05/2020.

3 Os textos A invenção de uma epidemia, Contágio, Esclarecimentos, Distanciamento Social, Reflexões sobre a peste e Uma pergunta foram publicados pela Editora italiana Quodlibet. Os textos no original podem ser acessados pela homepage da editora: https://www.quodlibet.it/una-voce-giorgio-agamben. As traduções dos textos para o português podem ser lidas em Reflexões sobre a peste: ensaios em tempos de pandemia, publicadas em 11 de maio sob a forma de e-book pela editora Boitempo, de autoria de Isabella Marcatti e de Luisa Rabolini. Todas as referências destacadas do texto seguem a fórmula: autor, texto, parágrafo. A numeração dos parágrafos segue tanto a organização dos textos em italiano como das traduções em português.
} 
articulado por Agamben em seus textos. Não se trata, portanto, de uma defesa da posição filosófica do filósofo - cujas declarações geraram uma série de objeções por parte de seus críticos -, mas se trata de um esforço de recondução de sua fala ao locus de seu pensamento político: a normalização do paradigma da exceção como forma de governo nas democracias contemporâneas e a politização dos dispositivos sanitários característico da biopolítica

\section{Invenção de uma epidemia}

O primeiro texto de Giorgio Agamben sobre a atual emergência sanitária é intitulado $A$ invenção de uma epidemia, e foi publicado em 26 de fevereiro pela Quodlibet'. No momento que o filósofo escreve, a Itália registra seis mortes por coronavírus e o governo, que havia decretado estado de emergência em 31 de janeiro, apresentava-se aparentemente confiante ${ }^{5}$. Neste contexto o filósofo escreve:

Frente às medidas de emergência frenéticas, irracionais e completamente injustificadas por uma suposta epidemia devido ao coronavírus, é necessário partir das declarações da CNR [Consigilo Nažionale delle Ricerche - Conselho Nacional de Investigação/Pesquisa], segundo as quais [...] 'não há nenhuma epidemia de SARS-CoV-2 na Itália (AGAMBEN, Invenção, \$1).

De imediato, a expressão "suposta epidemia" uma série de críticas ao filósofo: a maior parte delas acusa Agamben de subestimar a gravidade da doença e a seriedade de seu efeito sobre a sociedade 6 . A estratégia da crítica é destacar a atitude negacionista do filósofo italiano, destacando, sobretudo, a tese agambeniana segundo a qual a epidemia é uma "invenção", isto é, um artifício político empregado pelos regimes democráticos contemporâneos como meio de instaurar o estado de exceção, concretizando o projeto totalitário que une democracia e tirania desde a Revolução Francesa, no século XVIII. Uma parte das críticas argumenta que, no tocante a tese da "invenção", Agamben negligencia os fatos concretos e os dados estatísticos e menospreza a tragicidade do fenômeno da pandemia, procurando adequar a realidade ao seu próprio léxico político. Outra parte da crítica dedica-se a mostrar as inconstâncias das leituras de Agamben sobre a função e a finalidade das instituições - o Estado, a Igreja - e de suas figuras políticas.

${ }^{4}$ Cf.: https://www.quodlibet.it/giorgio-agamben-I-invenzione-di-un-epidemia. A versão traduzida em português pode ser acessada através do link: https://medium.com/@sarawagneryork/a-inven\%C3\%A7\%C3\%A3o-de-uma-epidemiad4a15dbf9f14. Acessado 16/04/2020.

5 Os primeiros casos de CoV-2 na Itália são registrados em 30 de janeiro de 2020. 0 primeiro-ministro italiano, Giuseppe Conte, em pronunciamento afirma: "Podemos tranquilizar todos os cidadãos. A situação está absolutamente sob o controle". No dia 25 de fevereiro, a Itália registra 6 mortes e o governo continua aparentemente confiante: "A Itália é um país seguro, onde se pode viajar, fazer turismo...". No dia seguinte, 26 de fevereiro, dia em que Agamben publica o primeiro texto, Milão lança a campanha: "Milão não para", estimulando moradores a manter atividades econômicas e sociais. 0 quadro sanitário da Itália só mudará no dia 8 de março, no momento em que as mortes sobem mais de $50 \%$ e quando o governo muda radicalmente de tom: "Estamos enfrentando uma emergência", como declarou o primeiro-ministro italiano. Somente no dia seguinte, em 9 de março, após 400 mortes, o Estado italiano impõe medidas excepcionais ao decretar quarentena nacional. Cf.: https://www.youtube.com/watch?v=5NJaUIHtwOo\&t=267s. Acessado em 16/05/2020.

6 Em 24 de março de 2020 o jornal Le Monde publica a entrevista de Nicolas Truong com Giorgio Agamben, na qual o jornalista pergunta se o filósofo "se arrepende" das declarações dadas: "Em vista do número de vítimas e da rápida propagação do vírus, em particular na Itália, você se arrepende dessas palavras?". A resposta de Agamben é precisa: "Não sou nem virologista nem médico e, no artigo em questão, que data de um mês, me limitava a citar textualmente o que era então opinião do Conselho Nacional de Pesquisa italiano". A entrevista completa e traduzida para o espanhol pode ser acessada em: https://artilleriainmanente.noblogs.org/?p=1381\&fbclid=IwAROHN9kW6R79bryfpOAQ SZhprzd2pOi3obgeKfCYoOIfJrCdd7KIEzuMekw. Acessado em 16/05/2020. 
Em resposta à polêmica levantada por suas declarações a estratégica de Agamben é enfatizar o locus de sua argumentação: o autor fala como filósofo, de modo que não tem a pretensão de fazer uma análise epidemiológica, virológica ou econômica da pandemia. O problema proposto é, portanto, não de ordem médica, mas de ordem política: se as declarações oficiais dadas pelo governo italiano afirmam que a Itália é um país seguro, qual é, portanto, a justificativa para o decreto de estado de exceção? Em uma outra formulação: se os dados estatísticos apontam para a ausência de uma "epidemia" por CoV-2 na Itália, qual seria a necessidade para a adoção das medidas excepcionais?7. O argumento de Agamben é de que parece haver um desarranjo entre o discurso oficial e as medidas sociais:

Se essa é a situação real, por que a mídia e as autoridades se esforçam em espalhar um clima de pânico, causando um estado real de exceção, com sérias limitações de movimentos e uma suspensão do funcionamento normal das condições de vida e trabalho em regiões inteiras? (AGAMBEN, Invenção, \2).

Entre a "situação real”, na qual o coronavírus é, como descreve o CNR, "um tipo de gripe”, e o "clima de pânico" espalhado pelas autoridades e meios de comunicação há um descompasso. A questão deve ser recolocada: se não há emergência sanitária, qual a finalidade da adoção das medidas de emergência? Para Giorgio Agamben, tais medidas foram decretadas em vista do efeito que elas produzem: o pânico que como fator de instabilidade pública justifica o decreto de estado de exceção.

\subsection{Exceção e Necessidade}

Em Homo sacer II, Agamben define a excȩão como "O dispositivo original graças ao qual o direito refere-se à vida e a inclui em si por meio de sua própria suspensão” (AGAMBEN, 2004, p. 12). O termo dispositivo, herdado do léxico foucaultiano, designa, por sua vez, discursos, instituições, edifícios, proposições filosóficas e medidas, cuja função estratégica é capturar e governar a vida: "a função dos dispositivos é, precisamente, a de capturar o vivente, dando lugar, por meio dessa captura, aos processos de subjetivação e dessubjetivação" (CASTRO, 2013, p. 164) . Como dispositivo a excȩ̧ão designa um conjunto de medidas adotadas constitucionalmente com a função de capturar a vida humana por meio da suspensão do ordenamento jurídico - isto é, por meio da própria suspensão da lei.

Ao suspender a lei - os direitos civis -, entretanto, o indivíduo não é excluído do ordenamento jurídico, mas incluído nele. Sob a exceção a vida humana encontra-se unida e ao mesmo tempo abandonada ao direito, isto é, exposto à sua violência. Funcionando conforme o paradigma da exclusão-inclusão, isto é, operando de uma zona de indiscernibilidade entre o externo e o interno, entre direito e vida, Agamben sustenta que o estado de exceção é o dispositivo por meio do qual o poder soberano - "soberano é aquele que decide sobre o estado de exceção" - captura a vida por completo e é, propriamente, a "forma legal daquilo que não tem forma legal” (AGAMBEN, 2004, p. 12). A forma política do estado de exceção é paradoxal porque as medidas jurídicas adotadas por ele são decretadas com o respaldo constitucional, porém

\footnotetext{
7 Previsto pela Constituição Federal brasileira, o decreto de "estado de exceção" deve respeitar os princípios de necessidade (ocorrência de um evento fático) e de temporaridade (tempo necessário para execução da medida), sob o risco dar lugar a impulsos autoritários por parte do poder executivo. Cf. https://jus.com.br/artigos/64282/estadode-defesa-e-estado-de-sitio. Acessado: 16/04/2020.

8 CASTRO, E. Introdução a Giorgio Agamben: uma arqueologia da potência. Tradução: Beatriz de Almeida Magalhães. 1. reimp. Belo Horizonte: Autêntica Editora, 2013.
} 
excedem o campo da jurisdição e não podem, portanto, serem compreendida no plano do direito ${ }^{9}$. Nessa perspectiva, o estado de exceção não é uma anomalia política, mas a zona limítrofe entre a política democrática e a política autoritária, entre poder popular e poder soberano.

Em Homo sacer II Agamben enfatiza que os decretos de exceção são frutos de períodos de crise política. São fatores de crise aqueles eventos que podem causar instabilidade social e institucional, cabendo ao estado de exceção - ou "estado de defesa" - prontamente reestabelecer e preservar a ordem pública ou a paz social. Dentre os fatores que figuram como produtores de crise estão os desastres ambientais de grandes proporções, a iminência de amplas rebeliões, grave instabilidade institucional e recessões econômicas. Todos esses se enquadram no princípio de necessidade que serve de critério de justificativa ao acionamento do estado de exceção ${ }^{10}$.

Previsto na Constituição Federal de países democráticos o estado de exceção é "a resposta imediata do poder estatal aos conflitos extremos". Entretanto, ele também é responsável por produzir o sentimento de "insegurança" e de "risco" com o qual ele se justifica diante do princípio da necessidade. "Frenéticas", "irracionais" e "desmotivadas" são adjetivos que o filósofo utiliza para designar a adoção de medidas de exceção em contexto em que está ausente a ameaça sanitária que legitima os decretos de emergência ${ }^{11}$. O que, porém, explica a "desproporcionalidade" das medidas na opinião do filósofo italiano? Segundo Agamben:

Em primeiro lugar, há uma tendência crescente a utilizar o estado de exceção como paradigma normal de governo. (...) E o outro fator, não menos inquietante, é o estado de medo que evidentemente se estendeu nos últimos anos nas consciências dos indivíduos e que se traduz em uma necessidade real dos estados de pânico coletivo, a quem a epidemia volta a oferecer o pretexto ideal (AGAMBEN, Invenção, $\mathbb{S}$ 3).

Agamben enfatiza que a "desproporção" das medidas de exceção é um hábito governamental dos regimes democráticos contemporâneos. Muito antes da pandemia por covid-19, Homo sacer II, publicado em 2003, Agamben já havia esboçado uma "breve história do estado de exceção", na qual se verifica que a elaboração e primeira aplicação do dispositivo da exceşão coincide com a Revolução Francesa ${ }^{12}$. Desde então, a história do estado de exceção traçada mostra que são inúmeros os exemplos de sua aplicação no seio da República ou do Estado Democrático de Direito - seja no caso de guerras internacionais ou de guerras civis,

9 "O estado de exceção não é um direito especial (como o direito da guerra), mas, enquanto suspensão da própria ordem jurídica, define seu patamar ou seu conceito limite" (AGAMBEN, Giorgio. Estado de exceção: homo sacer II, 1. Trad. Iraci D. Poleti. $2^{\mathrm{a}}$ ed. São Paulo: Boitempo, 2004, p. 15).

10 "Uma opinião recorrente coloca como fundamento do estado de exceção o conceito de necessidade. Segundo o adágio latino muito repetido (...) necessitas legem non habet [St. Agostinho], ou seja, a necessidade não tem lei, o que deve ser entendido em dois sentidos opostos: 'a necessidade não conhece nenhuma lei' e 'a necessidade cria sua própria lei'. Em ambos casos, a teoria do estado de exceção se resolve integralmente na do status necessitatis (...) A teoria da necessidade não é aqui outra coisa que uma teoria da exceção (dispensatio) em virtude da qual um caso particular escapa à obrigação da observância da lei" (AGAMBEN, 2004, p. 40s).

11 Roberto Esposito afirma algo semelhante: "Naturalmente, do ponto de vista jurídico, o estabelecimento de uma emergência, há muito aplicada mesmo em casos em que não há necessidade, empurra a política para procedimentos excepcionais que podem, a longo prazo, minar o equilíbrio do poder em favor do executivo" (ESPOSITO, Tratados a todo custo, § 2). Cf. https://medium.com/@rondnunes/tratados-a-todo-custo-de-roberto-esposito-5b74ab4cdacd. Acessado em 17/05/2020.

12 “Já vimos como o estado de sítio teve sua origem na França, durante a Revolução. Depois de sua instituição pelo decreto da Assembleia Constituinte de 8 de julho de 1791, ele adquire fisionomia própria de état de siège fictif ou politique com a lei do Diretório de 27 de agosto de 1797 e, finalmente, com o decreto napoleônico de 24 de dezembro de 1811" (AGAMBEN, 2004, p. 24 - itálicos do autor). 
seja em casos de emergência ecológica ou econômica (AGAMBEN, 2004, p. 38).

A segunda explicação para as desproporcionais medidas de exceção é o fator medo, que se manifesta coletivamente como pânico, isto é, como sentimento de risco à vida ou sobrevivência da comunidade. O pânico coletivo característico das sociedades contemporâneas é sintoma de que o contexto político em que vivemos o "estado de exceção é a norma”. O regime da ditadura constitucional - isto é, do regime de exceção previsto por Constituição Federal - é, por excelência, o paradigma de governo que gerencia a vida nas sociedades contemporâneas, como demonstra Agamben em Homo Sacer II (AGAMBEN, 2004, p. 21). Se "nos últimos anos" o medo está internalizado na consciência dos indivíduos da sociedade contemporânea é porque ele foi produzido sobre o corpo a partir de uma série de dispositivos "disciplinares e biopolíticos", tais como identificados por Michel Foucault (1926-1984) na terceira parte de Vigiar e Punir (1975) - "Disciplina" 13. Nesse contexto, os inúmeros decretos de proibições, suspensões e isolamento previstos por "razões de higiene e segurança pública" não são mais que os efeitos da normatização dos regimes de exceção nas democracias contemporâneas ${ }^{14}$.

Embora o estado de exceção seja o paradigma da política moderna e contemporânea, Agamben acredita que o modo como ele está sendo aplicado atualmente é inédito:

A desproporção diante do que, segundo o CNR, é uma influenza normal, não muito diferente das que ocorrem todos os anos, chama atenção. Parece que uma vez esgotado o terrorismo como causa de medidas excepcionais, a invenção de uma epidemia poderia oferecer o pretexto ideal para estendê-los além de todos limites (AGAMBEN, Invenção, \4).

Segundo o filósofo, na ausência da ameaça armada e beligerante de um inimigo externo, a epidemia funciona como justificativa para os decretos de exceção. Esse processo, segundo Agamben, é circular: "Assim, em um círculo vicioso perverso, a limitação da liberdade imposta pelos governos é aplicada em nome de um desejo de segurança que foi induzido pelos mesmos governos que agora interveem para satisfazê-la" (AGAMBEN, Invenção, \5). Isto quer dizer que toda "ditadura constitucional" - ou seja, estado de exceção - é prisioneira do "círculo vicioso segundo o qual as medidas excepcionais, que se justificam como sendo para a defesa da constituição democrática, são aquelas que levam à sua ruína”. (AGAMBEN, 2004, p. 20).

Dentre os fatores que levam a democracia à ruína está aquele conjunto de medidas adotadas em estado de emergência sanitária e a que Agamben chama de "graves restrições à liberdade": a) proibição da remoção do município, b) proibição de acesso ao município ou área em questão, c) suspensão de eventos ou iniciativas de qualquer natureza, de eventos e de qualquer forma de reunião em local público ou privado, inclusive cultural, recreativo, esportivo e religioso, mesmo que realizados em locais fechados e abertos ao público; d) suspensão de serviços educacionais para crianças e escolas de todos os níveis, bem como a frequência das atividades escolares e de ensino superior, exceto as atividades de ensino à distância; e) suspensão

13 Dentre os exemplos dados por Foucault figuram a divisão arquitetônica das instituições disciplinares na escola, prisão, hospital e manicômio, o controle temporal das atividades, a organização espacial dos ambientes e as técnicas de "adestramento", tais como a vigilância hierárquica, a sanção normalizadora, o exame e o panóptico. Cf. FOUCAULT, M. (1975) Vigiar e Punir. Trad. Raquel Ramalhete. 42a ed. Petrópolis, RJ: Vozes, 2014, p. 133-219.

14 Roberto Esposito (1950-), filósofo italiano, em texto sobre a pandemia Os partidos e o vírus: a biopolítica no poder, publicado em 28 de fevereiro de 2020, em resposta ao texto de Agamben diz: Afetadas por práticas profiláticas, ao mesmo tempo protegidas e mantidas à distância, são partes inteiras da população, consideradas em risco, mas também portadoras de risco de contágio. Esse também é o resultado da verdadeira síndrome imunitária que há muito tempo caracteriza o novo regime biopolítico teme, mais do que o próprio mal, é sua circulação descontrolada em um corpo social exposto a processos de contaminação generalizados". Cf.: http://www.ihu.unisinos.br/78-noticias/596698-os-partidos-e-o-virus-a-biopolitica-no-poder. Acessado em 18/05/2020. 
dos serviços de abertura ao público de museus e outros locais culturais referidos; f) suspensão de todas as viagens educacionais, nacionais e internacionais; g) suspensão dos processos essenciais e de utilidade pública; h) aplicação da medida de quarentena com vigilância ativa entre os indivíduos que tiveram contato próximo com casos de doença infecciosa difusa.

No texto $A$ invenção de uma epidemia a atenção de Agamben se concentrará sob o aspecto político da pandemia. O filósofo não parece estar preocupado em apresentar um diagnóstico da gravidade da doença nem em elaborar um quadro sobre o impacto econômico da crise sanitária. Sua intenção é revelar as implicações no campo da ética e da sociedade a instauração de um estado político que governa sob a forma de estado de exceção. Entretanto, as teses contidas no texto geraram uma série de objeções contra o filósofo italiano - tanto em seu território natal como no restante da Europa ${ }^{15}$. Aqui no Brasil, até o momento, três ensaios foram publicados sobre a polêmica ${ }^{16}$. A maior parte das críticas o acusam de leviandade diante da "verdade factual" dos milhares de mortos pelo novo coronavírus na Itália e por desprezar a fala técnica dos especialistas e cientistas.

Não parece, entretanto, ser objetivo de Agamben prover explicações sanitárias ou econômicas para a atual pandemia; antes, como filósofo crítico tanto do Estado democrático que governa sob o paradigma da excę̧ão quanto do uso histórico da ciência com fins morais, políticos, ideológicos e raciais Agamben prefere denunciar a fusão entre política e biossegurança ${ }^{17}$.

\section{Contágio}

Em 11 de março é publicado pela Quodlibet o segundo texto de Giorgio Agamben, Contágio ${ }^{18}$. Nesta mesmo data, a OMS anuncia o novo coronavírus como pandemia global. É nesse contexto que o filósofo analisará a noção de "contágio", conceito que designa, na leitura do filósofo, um dispositivo biopolítico engendrado nos sécs. XIV ao XVII:

15 O primeiro intelectual a criticar as declarações de Giorgio Agamben foi o filósofo francês, Jean-Luc Nancy (1940-), em um texto intitulado Exceção viral, de 28 de fevereiro de 2020, publicado no site Antinomie.it. A tradução em português pode ser acessada em: https://medium.com/@rondnunes/exce\%C3\%A7\%C3\%A3o-viral-de-jean-lucnancy-96446a71e4c6. Acessado em 17/05/2020.

16 Até o momento três ensaios foram publicados sobre a polêmica iniciada por Agamben: Agamben sendo Agamben; o filósofo e a invenção da pandemia, da autoria de Yara Frateschi, publicado no dia 15 de maio de 2020; Agamben na Cidade de Deus, em resposta a Yara por Ricardo, publicado por Evandro S. Martins em 13 de maio de 2020; e, por fim, um segundo texto em resposta a Yara, intitulado Agamben sendo Agamben: por que não?, da autoria coletiva de Carla Rodrigues, Ana Carolina Martins, Caio Paz, Isabela Pinho e Juliana de Moraes Monteiro e publicado em 16 de maio de 2020.

17 Em texto ulterior intitulado Biossegurança e política, o décimo segundo da coletânea de ensaios sobre a pandemia, Agamben defende que na atual pandemia está "em questão o desenho de um paradigma de governo cuja eficácia supera muito a de todas as formas de governo que a história política do Ocidente já conheceu" (AGAMBEN, Biossegurança, § 6). Ainda segundo o autor: “(...) a organização integral do corpo dos cidadãos, a fim de fortalecer ao máximo a adesão às instituições governamentais, produzindo uma espécie de civismo superlativo em que as obrigações impostas são acrescentadas como prova de altruísmo, e o cidadão não tem mais um direito à saúde (health safety), mas se torna juridicamente obrigado à saúde (biosecurity). (...) Se, no progressivo declínio das ideologias e das fés políticas, as razões de segurança já permitiram que os cidadãos aceitassem limitações às liberdades que antes não estavam dispostos a aceitar, a biossegurança provou ser capaz apresentar a absoluta cessão de toda atividade política e de toda relação social como forma máxima de participação cívica" (ibid., § 5ss).

18 Cf.: https://www.quodlibet.it/giorgio-agamben-contagio. A versão traduzida está disponível em: https://medium.com/textura/cont\%C3\%A1gio-por-giorgio-agamben-eab8aaa8a6ea 
Uma das consequências mais desumanas do pânico que se busca espalhar por todos os meios na Itália durante a chamada epidemia de coronavírus é a própria ideia de contágio, que está na base das medidas excepcionais de emergência adotadas pelo governo. A ideia, estranha à medicina hipocrática, teve seu primeiro precursor inconsciente durante as pragas que assolaram algumas cidades italianas entre $1500 \mathrm{e}$ 1600 (AGAMBEN, Contágio, \1).

Os estudos da arqueologia filosófica do código hipocrático ${ }^{19}$ demonstrou que a noção de "contágio" está ausente do léxico médico da Antiguidade clássica. O que, porém, não significa que a Antiguidade ignorasse o que vinha a ser uma pandemia. Entretanto, como destaca Agamben, a noção de "contágio" é produto das experiências com as pandemias do fim da Idade Média e início das Modernidade - sobretudo nos sécs. XVI e XVII, séculos particularmente assolados por constantes pragas, epidemias e pestes.

No contexto atual da pandemia por covid-19 Agamben acredita que a "ideia do contágio" é elemento narrativo que fundamenta a adoção das medidas excepcionais do decreto de estado de exceção. Ela é particularmente "desumanizadora" na medida em que transforma o cidadão em um agente de contaminação, como é possível verificar no exemplo dado pelo filósofo: "É a figura do untore, o infectador, imortalizada por Manzoni em seu romance e no ensaio sobre a 'História da Coluna Infame"' (AGAMBEN, Contágio, \1).

Guardadas as devidas proporções, a figura folclórica do untori, isto é, do "propagador da peste"20, é utilizada por Agamben como metáfora para o processo de desumanização que ocorre dentro dos espaços de exceção: campo de trabalho forçado, campo de concentração, campo de detenção, campo de disciplina. No romance Os noivos do poeta, romancista e filósofo italiano Alessandro Manzoni (1785-1873), a figura do untore era representada em meio às praças públicas e casas particulares espalhando o "odor fétido" da praga, oferecendo auxílio monetário a quem da comunidade o auxiliasse a propagar a peste. Segundo a crença popular registrada por Manzoni, o untore era tido como causa da contaminação pela peste e considerado como o principal vetor de contágio da peste.

Ao mobilizar a metáfora popular do untore para traduzir o fenômeno do contágio, o objetivo almejado por Giorgio Agamben explicar o fenômeno do "bode expiatório", isto é, da figura estigmatizada cuja morte ou encarceramento representa a expiação do mal coletivo:

Dadas as diferenças, as disposições recentes (adotadas pelo governo com decretos que gostaríamos de esperar — mas é uma ilusão — não terem sido ratificadas pelo parlamento em leis nos termos previstos) transformam de fato cada indivíduo em um potencial infestador, da mesma maneira que aqueles que lidam com o terrorismo consideram de fato e de direito cada cidadão como um potencial terrorista. A analogia é tão clara que o interlocutor em potencial que não cumprir as prescrições é punido com prisão (AGAMBEN, Contágio, \3).

Trata-se, portanto, de uma analogia: a figura do terrorista na primeira década do séc. XXI, equivale à figura do untore no séc. XVII e XVIII. Ambas, equivalendo, à figura do indivíduo contaminado pelo CoV2, agora na segunda década do séc. XXI. Contra as figuras invisíveis do terrorista e do "portador saudável

19 Corpus Hippocraticum é uma coletânea de cerca de 60 tratados do início da Grécia Clássica que, embora tenha muitas vezes sua vinculada a Hipócrates de Cós (460-377 a.C.), em seu conjunto não pode ser atribuído a nenhum autor específico. A obra é considerada um esforço coletivo que engloba grande diversidade filosófica e pluralidade de práticas médicas de variados autores gregos.

20 Untore", ou "untori", foi termo italiano utilizado para o "untador", o indivíduo que, durante os períodos da peste bubônica (especialmente durante o ano de 1630 em Milão) e segundo a crença popular, untava as casas com uma poção que propagava a peste e a cólera. Contra o "untore" se voltou a ira popular e jurídica, sendo ele passível de sofrer linchamentos públicos e condenação, sem provas, por parte da justiça. Cf. https://dizionari.corriere.it/dizionario_italiano/U/untore.shtml. Acessado em 17/05/2020. 
ou precoce, que infecta uma multiplicidade de indivíduos" sem ser capaz de ser defender contra ela, são engendradas verdadeiras "guerras" - tal como é evidente pelas expressões "guerra ao terrorismo" e "guerra ao coronavírus" utilizada pela OMS e pelos meios de comunicação.

Entretanto, Giorgio Agamben chama a atenção do leitor para uma consequência ainda mais grave do que as disposições e medidas excepcionais em si:

Ainda mais triste do que as limitações das liberdades implícitas nas disposições é, na minha opinião, a degeneração das relações entre os homens que elas podem produzir. O outro homem, quem quer que seja, mesmo um ente querido, não deve se aproximar ou tocar um ao outro e devemos colocar entre ele e ele uma distância [...] Nosso próximo foi abolido (AGAMBEN, Contágio, \3).

No texto A invenção de uma epidemia Agamben destaca o conjunto da suspensão das chamadas liberdades individuais previstas pelos decretos de exceção. Em termo políticos, as medidas excepcionais são responsáveis, na opinião do filósofo, pela degeneração das relações entre os indivíduos da comunidade, uma vez que o risco do contágio estabelece severas limitações ao contato pessoal e interpessoal. No distanciamento social, o próximo é abolido e, junto dele, a comunidade política, isto é, o conjunto de cidadãos que em sua ação deliberam e decidem sobre o governo e o funcionamento da sociedade ${ }^{21}$.

O ponto central na argumentação de Agamben em Contágio vê, na "inconsistência ética dos governantes", a causa tanto do pânico da contaminação como do pânico provocado pelas medidas excepcionais:

É possível, dada a inconsistência ética de nossos governantes, que essas disposições sejam ditadas pelo mesmo temor que pretendem provocar, mas é difícil não pensar que a situação criada é exatamente a que aqueles que nos governam tentaram realizar repetidamente: que universidades e escolas sejam fechadas de uma vez por todas e que as lições sejam dadas apenas de forma online, que paremos de nos encontrar e conversar por razões políticas ou culturais e apenas troquemos mensagens digitais. E que, tanto quanto for possível, as máquinas substituam todo contato — todo contágio - entre os seres humanos (AGAMBEN, Contágio, \3).

O termo "disposições" equivale ao termo "dispositivo", com o qual Foucault e Agamben designam discursos, medidas, arquiteturas, leis e proposições filosóficas que intentam capturar a vida humana em meio a rede do poder disciplinar e biopolítico ${ }^{22}$. A pandemia por CoV-2 revela, portanto, que os Estados Democráticos contemporâneos utilizam a noção de "contágio" - engendrada nos sécs. XVI e XVII, aperfeiçoada no início do séc. XX via ciências médicas e tecnológicas - como dispositivo na busca do controle social. Dentre as medidas de "gestão da vida" estão: a) o fechamento das escolas e universidades e implementação global dos cursos de ensino à distância, privado ou público - cuja consequência imediata é a precarização do ensino presencial e declínio do espaço da sala de aula; b) interrupção das conversas e encontros motivados por temas políticos e culturais; c) comunicação humana apenas por meios virtuais; d) substituição de todo

${ }^{21}$ Em texto publicado no dia 28 de fevereiro, em resposta às objeções de Jean-Luc Nancy à Giorgio Agamben, Roberto Esposito defende a mesma tese do filósofo italiano: "Pelo contrário, mesmo o termo 'viral' indica uma contaminação biopolítica em diferentes línguas - políticas, sociais, médicas, tecnológicas - unificada pela mesma síndrome imunológica, entendida como uma polaridade semanticamente contrária ao léxico da communitas" (ESPOSITO, Tratados a todo custo, p. 1).

22 “(...) Foucault, ao final da Vontade de saber, resume o processo através do qual, nos limiares da Idade Moderna, a vida natural começa, por sua vez, a ser incluída nos mecanismos e nos cálculos do poder estatal, e a política se transforma em biopolítica: 'Por milênios, o homem permaneceu o que era para Aristóteles: um animal vivente e, além disso, capaz de existência política; o homem moderno é um animal em cuja política está em questão a sua vida de ser vivente' [FOUCAULT, 1976, p. 127]" (AGAMBEN, 2010, p. 11). 
contato-contágio humano pelas relações assépticas entre seres humanos, por meio das máquinas e dos eletrônicos.

$\mathrm{Na}$ continuação dos textos sequentes, Agamben analisa pormenorizadamente as graves consequências para a política e a ética da crise sanitária, econômica e antropológica da pandemia por covid-19. O cerne de sua tese consiste em enxergar os atuais decretos de estado de exceção por motivos de emergência sanitária como um laboratório político, nos quais os governos democráticos contemporâneos testam e avaliam o alcance do controle do poder soberano ${ }^{23}$. Chama atenção que em Contágio Agamben defende que nas atuais sociedades de laboratório, o contato humano coincide com contágio e a troca humana apresenta-se como possível risco de morte. O paradigma imunitário substitui, neste sentido, o paradigma político como forma de governo.

Em Aprendendo com o vírus, publicado em Sopa de Wuban - coletânea de textos filosóficos sobre a atual pandemia -, o filósofo transgênero espanhol Paul Beatriz Preciado (1970-) traça um paralelo entre as noções de comunidade e de imunidade, a partir da tese do filósofo italiano Roberto Esposito (1950-):

O filósofo italiano Roberto Esposito analisou as relações entre a noção política de 'comunidade' e a noção biomédica e epidemiológica de 'imunidade'. Comunidade e imunidade compartilham de uma mesma raiz, munus, em latim o munus era o tributo que alguém deveria pagar por viver ou tomar parte da comunidade [uma espécie de taxa de condomínio arcaica]. A comunidade é cum (com) munus (dever, lei, obrigação, mas também oferenda): um grupo humano ligado por uma lei e uma obrigação comum, mas também por um presente, por uma oferenda. O substantivo immunitas, é um vocábulo privativo que deveria negar o munus. No direito romano, a immunitas era uma dispensa ou um privilégio que exonerava alguém dos deveres cívicos que são comuns a todos. Aquele que havia sido exonerado era imune. Da mesma forma que aquele que estava desmunido era aquele que se havia tirado todos os privilégios da vida em comunidade (PRECIADO, 2020, p. 165) ${ }^{24}$.

Conforme a etimologia apresentada por Esposito, "comunidade" é o cum - munus, isto é, o conjunto dos indivíduos que pagam o "tributo comum" - o imposto - e que, dessa maneira, obtinham o direito de viver em uma determinada localidade: a cidade. Por outro lado, o $i$-munus, o indivíduo que estava isento da cobrança dos tributos e, consequentemente, privado da vivência em comunidade. A "imunidade" era, portanto, qualidade daqueles que, na Antiguidade Tardia romana, não possuíam o direito de participar das decisões públicas e das deliberações políticas da cidade. Mais do que isentos, os “imunizados” estão privados da participação política.

Em seu texto Preciado destaca que para Esposito "toda biopolítica é imunológica” (PRECIADO, 2020, p. 165). Isto é, trata-se de uma política que

supõe uma definição da comunidade e do estabelecimento de uma hierarquia entre aqueles corpos que estão isentos de tributos (os que são considerados imunes) e aqueles que a comunidade percebe como potencialmente perigoso [os imunodeficientes] e que serão excluídos em um ato de proteção imunológica. Esse é o paradoxo da biopolítica: todo ato de proteção implica uma definição imunitária da comunidade segundo a qual esta se dará a si mesma a autoridade de sacrificar outras vidas, em benefício de uma ideia de sua própria soberania. O estado de exceção é a normalização deste insuportável paradoxo

${ }^{23}$ Em Homo sacer II, 1 Agamben escreve: "A Primeira Guerra Mundial - e os anos seguintes - aparece, nessa perspectiva, como o laboratório em que se experimentam e se aperfeiçoam os mecanismos e dispositivos funcionais do estado de exceção como paradigma de governo" (AGAMBEN, 2004, p. 19).

24 Cf. PRECIADO, P. B. "Aprendendo com o vírus". In: Sopa de Wuhan: Pensamiento contemporâneo em tiempos de pandemias. Ideia, direção de arte, desenho e edição Pablo Amadeo, Editorial ASPO (Aislamiento Social Preventivo y Obligatorio), 2020. A tradução para o português é de minha autoria. 
(PRECIADO, 2020, p. 165-166).

A “somatopolítica", isto é, a política investida sobre o corpo, classifica os indivíduos de uma comunidade segundo distinções de ordem sanitária: de um lado o "corpo são" (imunizados) e, do outro, o "corpo doente" (imunodeficiente) ${ }^{25}$. Na leitura de Esposito, a política contemporânea funciona sob um paradoxo biopolítico: a vida, para ser protegida e conservada deve ser imunizada - tornada sã, isto é, produtiva. Isto quer dizer que o projeto político de proteção à vida pressupõe medidas de imunização que são, por sua vez, contrárias à própria política. Em nome da ordem pública, da imunidade sanitária e da estabilidade jurídicoinstitucional, o Estado Democrático suspende à autonomia da vida política, higienizando o tecido social ao sacrificar chamadas liberdades individuais. A política da vida - a biopolítica-, portanto, coincide com a política da morte -, cujo paradigma foi enunciado por Foucault: "fazer viver, deixar morrer" - a tanatopolítica ${ }^{26}$. $\mathrm{Na}$ tanatopolítica, as formas de vida improdutivas são "descartadas" em detrimento das formas produtivas de vida $^{27}$. As análises de Agamben e de Esposito demonstram que na atual política contemporânea a distinção entre "comunidade" e "imunidade" romana deixa de ter sentido e em seu lugar se dá uma espécie de espécie de fusão epistemológica em que a comunidade é formada, não mais pelos comunes, isto é, por aqueles que possuem uma obrigação comum, mas pelos imunes, à saber, por aqueles que compartilham a mesma imunidade biossocial. Trata-se, portanto, do surgimento de uma sociedade higienizante, que em sua assepsia política, toma o contato humano como risco de exposição à morte.

As teses filosóficas de Foucault, de Agamben, de Esposito e de Preciado revelam, portanto, que a política moderna e a contemporânea se constituem na interseção de três formatos de poder: "biopolítica", "tanatopolítica" e "política imunitária". Tais conceitos, entretanto, constituem o núcleo do "estado de exceção" contemporâneo, sendo a exceção, por sua vez, a "normalização" do insuportável paradoxo da biotanatopolítica.

\section{Esclarecimentos}

O terceiro texto de Giorgio Agamben sobre a pandemia de CoV-2 é intitulado Esclarecimentos e foi publicado em 17 de março de $2020^{28}$. Como o título indica, ele foi escrito como réplica às más interpretações e distorções de suas colocações. O filósofo aproveita a oportunidade para esclarecer ao público em geral os pressupostos de seu pensamento político, desenvolvendo com mais clareza as premissas de seus argumentos.

25 "Para Foucault, as técnicas governamentais biopolíticas se estendiam como uma rede de poder que desdobrava o âmbito legal ou a esfera punitiva, convertendo-se em uma força 'somatopolítica', uma forma de poder especializado que se estendia em toda a totalidade do território até penetrar o corpo individual” (PRECIADO, P. B. (2020). Aprendendo com o vírus. Em Sopa de Wuhan, 2020, p. 164).

26 “(...) em todo Estado moderno, existe uma linha que assinala o ponto em que a decisão sobre a vida torna-se decisão sobre a morte, e a biopolítica pode deste modo converter-se em tanatopolítica (...)" (AGAMBEN, G. (1995) Homo sacer: o poder soberano e a vida nua I. Trad. Henrique Burigo. $2^{\mathrm{a}}$ ed. Belo Horizonte: Editora UFMG, 2010, p. 119).

27 "O conceito de 'vida sem valor' (ou 'indigna de ser vivida') aplica-se antes de tudo aos indivíduos que devem ser considerados 'incuravelmente perdidos' em seguida a uma doença ou ferimento e que, em plena consciência de sua condição, desejam absolutamente a 'liberação' (...) e tenham manifestado de algum modo este desejo" (ibid., p. 135).

28 Cf.: https://www.quodlibet.it/giorgio-agamben-chiarimenti. A versão traduzida está disponível em: https://medium.com/@paulbpreciado_ptbr/esclarecimentos-d01f7556bb90. Acessado: 19/04/2020. 


\subsection{Medo e vida nua}

O ponto de partida de Agamben é, mais uma vez, a problemática do "medo". Vimos anteriormente que em $A$ invenção de uma epidemia que o pânico é o dispositivo que justifica e aciona o estado de exceção. Em Esclarecimentos, entretanto, o filósofo toma o medo não só como dispositivo para o decreto de estado de exceção, como é também um fator revelador da natureza do fenômeno da pandemia por covid-19:

"O medo é um mau conselheiro, mas deixa à mostra muitas coisas que fingíamos não ver. O problema não é dar uma opinião sobre a gravidade da doença, mas se perguntar sobre as consequências éticas e políticas da epidemia. A primeira coisa que a onda de pânico que paralisou o país mostra claramente é que nossa sociedade não acredita em nada além da vida nua" (AGAMBEN, Esclarecimentos, \1).

Embora a medida de quarentena seja a única solução disponível para combater o vírus no momento em que não há uma vacina ou tratamento efetivo para ele, Agamben não parece estar preocupado em fazer diagnósticos do quadro epidêmico, menos ainda investigar as causas e os efeitos médicos do CoV-2, como fazem os virologistas e infectologistas. Sua principal preocupação é discutir as consequências éticas e políticas da atual pandemia. E o primeiro fator revelador da "onda de pânico" que o filósofo destaca mostra que a vida humana está reduzida à forma da vida nua.

Na obra Introdução a Giorgio Agamben: uma arqueologia da potência (2008) Edgardo Castro dá uma definição do significado técnico do termo "vida nua":

A vida do homo sacer, a vida nua, é a vida da qual se pode dispor sem necessidade de celebrar sacrifícios e sem cometer homicídio. (...) [esse corresponde ao] duplo caráter do homo sacer insacrificável, porém exposto à morte. (...) A sacralidade da vida nua configura-se, antes, não a partir de uma ambiguidade, mas de uma dupla exceção que a exclui, incluindo-a, tanto do direito divino, e por isso não pode ser objeto de sacrifício, como o direito dos homens, e por isso se pode dispor dela sem cometer homicídio. Não é a ambiguidade do sagrado o que a explica, mas seu isomorfismo com a relação de exclusão inclusiva do dispositivo soberano (CASTRO, 2013, p. 64ss).

A arqueologia filosófica empreendida por Agamben em Homo Sacer I: poder soberano e a vida nua mostra que o homo sacer era uma figura obscura do direito romano arcaico, cuja vida estava fora de jurisdição humana sem, contudo, estar fora da lei divina. A lei romana enquanto sanciona a sacralidade de uma pessoa ("aquilo que é sacer já está sob a posse dos deuses”- AGAMBEN, 2010, p. 75), autoriza sua morte (“ou, mais precisamente, torna-a impunivel" - AGAMBEN, 2010, p. 74). Abandonado pelo direito humano, mas ainda exposto ao direito divino, o homo sacer é a cifra da "impunidade da matança e a exclusão do sacrifício" (ibid., p. 83). O homem sagrado poderia ser morto por qualquer cidadão sem que com isso o agressor fosse acusado de homicídio. Como "homem sagrado" e, portanto, insacrificável, o homo-sacer estava, porém, abandonado pelo direito e exposto à violência humana ${ }^{29}$.

No léxico de Agamben a vida nua é a vida do homo sacer, a saber, a vida que não pode ser sacrificada pelo Estado, mas que qualquer cidadão - ou grupo social - poderia dispor dela sem qualquer implicação de sanção ou julgamento jurídico. A vida nua é a vida que é insacrificável e, ao mesmo tempo, matável. Em

\footnotetext{
29“Aquilo que é capturado no bando soberano é uma vida humana matável e insacrificável: o homo sacer. (...) Sacra, isto é, matável e insacrificável, é originalmente a vida no bando soberano, e a produção da vida nua é, neste sentido, o préstimo original da soberania. A sacralidade da vida (...) exprime, em sua origem, justamente a sujeição da vida a um poder de morte, a sua irreparável exposição na relação de abandono [jurídico]" (AGAMBEN, 2010, p. 85).
} 
outras palavras, trata-se de uma vida que é protegida pelo sistema jurídico - em acordo com o paradigma do "fazer viver" -, e, ao mesmo tempo, abandoada por ele: conforme o paradigma do "deixar morrer". A vida nua é, portanto, a vida descartável, isto é, a vida biológica ${ }^{30}$. No estado de exceção, a vida humana é reduzida à sua forma de vida nua - por isso Agamben utiliza termos como "desumanização" para caracterizar o processo investido sobre a vida do ser vivente na biotanatopolítica.

Em Esclarecimentos Agamben defende que no contexto da pandemia por covid-19 seus compatriotas estão dispostos a sacrificar todos os princípios que regem a política, a sociedade e a religião em nome do imperativo da sobrevivência da vida biológica:

É evidente que os italianos estão dispostos a sacrificar praticamente tudo - as condições normais da vida, as relações sociais, o trabalho e até mesmo as amizades, as afeições e convicções religiosas e políticas pelo perigo de adoecer. A vida nua - e o risco de perde-la não é algo que une as pessoas, mas que as cega e as separa (AGAMBEN, Esclarecimentos, $\$ 1$ ).

Ao adotar o imperativo conservação da vida biológica (a qoê) a sociedade contemporânea teria sacrificado a bíos, isto é, o conjunto das formas de vida que constituem a vivência em comunidade - isto é, política, propriamente dita ${ }^{31}$. Agamben defende que a ameaça representada pela contaminação por CoV-2 produz apego ao imperativo da sobrevivência, em detrimento da vivência ${ }^{32}$. Contudo, o medo de perder a vida biológica pelo contágio do vírus o tecido social, inviabilizando a política.

\subsection{Vida nua e estado de exceção}

Outro ponto destacado por Agamben em Esclarecimentos é o nexo entre vida nua - a vida própria do homo sacer- e estado de exceção:

A outra coisa, não menos preocupante que a primeira e que a epidemia deixou clara, é que o estado de exceção, ao qual os governos nos acostumam há algum tempo, de fato se tornou a condição normal. Houve epidemias mais graves no passado, mas ninguém jamais considerou declarar um estado de emergência como o de agora, que impede até que nos movamos. Os homens se acostumaram tanto a viver nas condições de crise e emergência perpétuas que parecem nem mesmo notar que suas vidas foram reduzidas a uma condição puramente biológica e perderam todas as suas dimensões, não só as sociais e políticas, mas até as humanas e afetivas (AGAMBEN, Esclarecimentos, \2).

Assim como o fenômeno da pandemia revela que, na biopolítica contemporânea, a vida humana (bíos) está reduzida à sua forma puramente biológica (zoé, ou vida nua), o fenômeno confirma a tese do filósofo alemão Walter Benjamin, em Sobre o conceito de história (1940), tese VIII: “a tradição dos oprimidos

${ }^{30}$ Aquelas vidas cuja existência ou inexistência não é de interesse do Estado. Não se deve interpretar que Agamben defende que as existem circunstâncias onde as vidas são consideradas obsoletas, mas sim no fato de que as pessoas em geral não perceberem que é do Estado o poder de definir qual vida é digna de ser vivida e qual não é (logo, biopolítica torna-se em verdade tanatopolítica).

31 "Os gregos não possuíam um termo único para exprimir o que nós queremos dizer com a palavra vida. Serviam-se de dois termos semântica e morfologicamente distinto, ainda que reportáveis a um étimo comum: zoé, que exprimia o simples fato de viver comum a todos os seres vivos (animais, homens e deuses) e bíos, que indicava a forma ou maneira de viver própria de um indivíduo ou de um grupo" (AGAMBEN, 2010, p. 9).

32 O filósofo sul-coreano, de nacionalidade alemã, Byung-Chul Han (1959-) compartilha de semelhante opinião: "O vírus nos isola e individualiza. Não gera nenhum sentimento coletivo forte. De alguma maneira, cada um se preocupa somente com sua própria sobrevivência" (Byung-Chul Han, A emergência viral e o mundo de amanhã, § 21). 
ensina-nos que o 'estado de exceção’ em que vivemos é na verdade a regra” (BENJAMIN, 2018, p. 13) 33.

$\mathrm{Na}$ obra Homo sacer II, 1 Agamben retoma a tese de Benjamin para concluir que, se o estado de exceção em que vivemos é a regra, isso ocorre porque as políticas modernas e contemporâneas funcionam sob o paradigma da suspensão e revogação dos direitos humanos e cívicos, como estratégia para assegurar a soberania do Estado Democrático (AGAMBEN, 2004, p. 21).

Em Esclarecimentos Agamben afirma que é a primeira vez na história ocidental que um estado de exceção é decretado por motivos de pandemia. Para o autor, nem mesmo na epidemia por peste bubônica nos sécs. XIV e XV, nem na "gripe espanhola" do início do séc. XX, medidas tão excepcionais foram decretadas. Entretanto, este dado apresentado pelo filósofo é falso. As medidas de emergência conhecidas como "isolamento social", ou "quarentena", foram aplicadas pela primeira vez no séc. XVII durante a pandemia por peste bubônica. Como notou a filósofa norte-americana Anastasia Berg em ensaio crítico como resposta a Agamben, Foucault já havia demonstrado que as pandemias que assolaram a Europa nos sécs. XVII e XVIII desencadearem medidas de isolamento social ${ }^{34}$. Se Agamben não desconhece esse fato ou se passou despercebido pelo filósofo não é possível afirmar com certeza; entretanto, a problemática levantada por Agamben é chamar atenção para um fato político contemporâneo: o hábito de vivermos em contextos de exceção e de emergências constantes.

Na continuação do texto de Esclarecimentos, Agamben escreve:

Uma sociedade que vive em um estado de emergência perpétuo não pode mais ser uma sociedade livre. $\mathrm{Na}$ verdade, vivemos em uma sociedade que sacrificou a liberdade pelos chamados 'motivos de segurança' e foi condenada a viver em um estado perpétuo de medo e insegurança (AGAMBEN, Esclarecimento, \2).

No trecho supracitado o tema do "sacrifício" aparece segundo o questionamento: quantos sacrifícios da liberdade faremos em nome da própria liberdade? Na opinião de Agamben não apenas os indivíduos sacrificam suas formas de vida pelo medo de adoecer, quanto a própria sociedade sacrifica sua liberdade e autonomia em virtude de uma emergência sanitária ${ }^{35}$. O medo do contágio pelo CoV-2 - o inimigo comum a todos e invisível - é, portanto, tanto causa das medidas excepcionais quanto forma própria da vida no contexto dos regimes de exceção. Contudo, como destacou Berg, Agamben "corretamente observa que a questão da proporção da resposta não é científica, mas moral” (BERG, 2020, p. 3). Isto quer dizer que, inicialmente, as medidas não foram adotadas em concordância com o estudo e o discurso dos especialistas, mas por uma justificativa política: a soberania.

O terceiro ponto destacado por Agamben em Esclarecimentos se trata da equivalência entre medidas emergenciais sanitárias e medidas excepcionais características do estado de sítio ${ }^{36}$ — a segunda, e mais grave,

33 BENJAMIN, W. (1940). "Sobre o conceito de história" em O anjo da história. Organização e tradução de João Barrento. $2^{\mathrm{a}}$ ed.; $2^{\mathrm{a}}$ reimp. Belo Horizonte: Autêntica Editora, 2018.

34 "Isto é falso. O mentor intelectual de Agamben, Michel Foucault detalha em Vigiar e Punir que no início dos anos de 1600, a preparação para a peste incluía restrições completas de movimento entre e dentro das cidades na Europa" (BERG, Anastasia A. “Giorgio Agamben's coronavírus cluelessness”. In The Chronicle of higher education, p. 3 - tradução livre). Cf.: https://www.chronicle.com/article/Giorgio-Agamben-s/248306. Acessado: 20/04/2020.

35 Ao fim da obra Constitutional Dictatorship: crisis government in the Modern Democracies (1948), Cliton Rossiter (1917-1970), historiador e cientista político norte-americano, afirma: "Nenhum sacrifício pela nossa democracia é demasiado grande, menos ainda o sacrifício temporário da própria democracia” (ROSSITER apud AGAMBEN, 2004, p. 22). Para o filósofo italiano, essas palavras soam de forma "grotesca".

36 O "estado de exceção" - de defesa ou de sítio - designam medidas extraordinárias previstas pela Constituição Federal brasileira, buscando reestabelecer ou garantir a continuidade da normalidade constitucional ameaçada. A 
forma do estado de exceção:

Não surpreende que para o vírus se fale de guerra. As medidas de emergência de fato nos obrigam a viver em condições de quarentena. Mas uma guerra contra o inimigo invisível que pode se esconder em qualquer outra pessoa é a mais absurda das guerras. É, na verdade, uma guerra civil. O inimigo não está fora, está dentro de nós (AGAMBEN, Esclarecimento, \3).

O uso do termo "guerra" para designar as medidas de combate e enfrentamento a pandemia por covid-19 - presente tanto no discurso do Diretor-geral da OMS como nos noticiários e meios de comunicação - é sintoma de que vivemos sob estado de sítio. Diante da normalização dos regimes de exceção, não surpreende a Agamben que o vírus seja identificado como inimigo número um do estado - substituindo antigas figuras políticas como a do terrorista. No contexto da pandemia que vivemos, os governos de exceção tomam o vírus como inimigo à paz pública, cuja presença na população requer intervenções da ordem beligerante. Dado que os vetores do contágio são os próprios cidadãos, o Estado trava contra eles uma espécie de guerra civil ${ }^{37}$.

Deste modo, no último parágrafo de Esclarecimentos Agamben questiona-se sobre o tipo de legado político que uma guerra civil contra um vírus pode transmitir ao futuro:

O que me preocupa não é tanto o presente, ou não só ele, mas o depois. Tal como as guerras legaram à paz uma série de tecnologias nefastas, do arame farpado às centrais nucleares, também é muito provável que os governos busquem continuar, mesmo depois da emergência sanitária, os experimentos que não conseguiram realizar antes: que as universidades e escolas sejam fechadas e que só deem aulas online, que deixemos de nos encontrar e falar por razões políticas ou culturais e só troquemos mensagens digitais, que sempre que possível as máquinas substituam todo e qualquer contato - qualquer contágio entre seres humanos (AGAMBEN, Esclarecimentos, \4).

Toda guerra produz tecnologias militares que foram, uma vez encerrado o conflito, disponibilizadas à população - sistemas de vigilância rádio, telefonia, antibióticos, computação e internet. Tais tecnologias são, porém, empregadas como dispositivos cuja finalidade é o controle social. Um exemplo desta possibilidade é dado por Byung-Chul Han, para quem as tecnologias produzidas para a vigilância social - biopolítica digital e psicopolítica digital - na Ásia servem atualmente de medidas para o enfrentamento da pandemia, podendo, ao fim dela, serem exportadas para a Europa38. Na opinião de Agamben, tal como encontramos

primeira forma do estado de exceção, o "estado de defesa" (inciso I, art. 136 da CF/88) busca "preservar ou prontamente restabelecer a ordem pública ou a paz social". A segunda forma do estado de exceção, o "estado de sítio", previsto no art. 137 da Constituição Federal, é acionado em três hipóteses: 1) comoção grave de repercussão nacional; 2) fatos que comprovem a ineficácia da medida tomada durante o Estado de Defesa; 3) declaração de estado de guerra ou resposta a agressão armada estrangeira.

37 Em Stasis: la guerra civile come paradigma politico - Homo sacer II, 2 (2015) ainda sem tradução em português, o filósofo italiano Giorgio Agamben procura estabelecer uma "stasiologia". Agamben, que não cria uma teoria da guerra civil, mas nos dá um esboço dela, procura demonstrar que a stásis, isto é, a "guerra civil", é o "limiar fundamental da politização do Ocidente", nos quais os âmbitos da cidade (polis) e da família (oikía) se sobrepõem. Assim como o conceito de "exceção" que, para Agamben, corresponde a uma zona de indiferença entre o dentro e o fora, entre o ordenamento jurídico e a vida nua, entre o político e o impolítico, a stásis - a guerra civil - é o ponto onde política e economia se determinam, consistindo na operação que torna o impolítico político e o político em econômico.

38 "Na China existem 200 milhões de câmeras de vigilância, muitas delas com uma técnica muito eficiente de reconhecimento facial. (...) Não é possível escapar da câmera de vigilância. (...) Toda a infraestrutura para a vigilância digital se mostrou agora ser extremamente eficaz para conter a epidemia. (...) Uma biopolítica digital que acompanha uma psicopolítica digital que controla ativamente as pessoas. (...) Não somente na China, como também em outros países asiáticos a vigilância digital é profundamente utilizada para conter a epidemia. (...) Como disse Naomi Klein, a comoção é um momento propício que permite estabelecer um novo sistema de governo. (...) Espero que após a 
no ensaio sobre a biossegurança e política, o estado de exceção "se aproveitará desse distanciamento para substituir, em toda a parte, os dispositivos tecnológicos digitais às relações humanas na sua fisicidade, que se tornaram suspeitas de contágio (contágio político, entenda-se)" (AGAMBEN, Biossegurança, \9). E, por fim, no último parágrafo deste mesmo ensaio, Agamben considera ser legitimo se questionar se tal sociedade "ainda poderá ser definida como humana ou se a perda das relações sensíveis, do rosto, da amizade, do amor pode ser verdadeiramente compensada por uma segurança de saúde abstrata e presumivelmente fictícia em sua totalidade" (ibid., § 12).

\section{CONCLUSÃO}

No conjunto de textos de Giorgio Agamben sobre a atual pandemia por Sars-CoV-2 procurei destacar os pontos principais da argumentação do filósofo italiano. A finalidade foi apresentar o quadro geral das teses e dos corolários desenvolvidos pelo filosofo. Verificou-se que no primeiro texto a "epidemia" é tida no contexto contemporâneo como um dispositivo de justificação para o decreto do estado de exceção. Mais do que um fator sanitário, a noção de epidemia é um produto, isto é, uma invenção, da bio-tanatopolítica exercida pelos Estados Democráticos desde o século XVIII. No segundo texto, Agamben procurou analisar as "consequências desumanizadoras" das medidas emergenciais que, entre outras, significa o declínio do contato humano, necessário ao exercício da política, pelo risco do contágio que transforma todo cidadão em vetor de contaminação. No terceiro texto, observou-se que Agamben oferece tanto um esclarecimento das questões levantadas nos textos anteriores quanto defende que a pandemia esclarece, por sua vez, o tipo sacrifício das formas tradicionais da vida humana - política, cultural e interpessoal - em nome da sobrevivência da vida biológica - ou seja, da vida nua.

O sacrifício das liberdades individuais por motivos de insegurança sanitária não são privilégio do séc. XXI, mas um hábito recorrente nos últimos séculos de utilizar a exceção como paradigma de governo, como demonstrou o filósofo. O efeito, porém, deste hábito não é outra senão a produção de uma guerra civil: a emergência de um inimigo invisível e atuante na comunidade que desperta medidas de enfrentamento características os conflitos beligerantes. Nos estados de emergência, Agamben identifica a presença de laboratórios da exceção, onde se almeja testar o controle biopolítico global sobre a população.

\section{REFERÊNCIAS}

AGAMBEN, G. (2003). Estado de exceção: homo sacer II, 1. Tradução: Iraci D. Poleti. $2^{a}$ ed. São Paulo: Boitempo, 2004.

. (1995). Homo sacer: o poder soberano e a vida nua I. Tradução: Henrique Burigo. $2^{a}$ ed. Belo Horizonte: Editora UFMG, 2010.

. (2015). Stasis: la guerra civile come paradigma politico - Homo sacer II, 2. Roma: Bollati Boringhieri, 2015.

. (2020). Reflexões sobre a peste: ensaios em tempos de pandemia. Tradução de Isabella

Marcatti e de Luisa Rabolini. São Paulo: Boitempo Editorial (11 de maio de 2020).

comoção causada por esse vírus não chegue à Europa um regime policial digital como o chinês. Se isso ocorrer, como teme Giorgio Agamben, o estado de exceção passaria a ser situação normal" (B.-C. HAN, A emergência viral e o mundo de amanhã. Cf.: http://vozes.com.br/a-emergencia-viral-e-o-mundo-de-amanha-byung-chul-han-o-filosofo-sulcoreano-que-pensa-a-partir-de-berlim/. Acessado 20/04/2020. 
. “L'invenzione di un'epidemia”. Una voce. Acessado em 16/04/2020 e encontrado em https://www.quodlibet.it/giorgio-agamben-I-invenzione-di-un-epidemia

. “Chiarimenti”. Una voce. Acessado em 19/04/2020 e encontrado em https://www.quodlibet.it/giorgio-agamben-chiarimenti

. "Contagio". Una voce. Acessado em 16/04/2020 e encontrado em https://www.quodlibet.it/giorgio-agamben-contagio

BBC NEWS BRASIL (2020). Cronologia: de pneumonia misteriosa a mais de 150 mil mortes por covid-19. Acessado em 16/04/2020 e encontrado em https://www.youtube.com/watch?v=5NJa UIHtwOo\&t=267s

BERG, A. “Giorgio Agamben's coronavírus cluelessness”. In The Chronicle of higher education, 2020.

BENJAMIN, W. (1940). “Sobre o conceito de história” In: O anjo da história. Organização e tradução de João Barrento. 2a ed.; $2^{\mathrm{a}}$ reimp. Belo Horizonte: Autêntica Editora, 2018.

CASTRO, E. (2008) Introdução a Giorgio Agamben: uma arqueologia da potência. Trad. Beatriz de Almeida Magalhães. 1. reimp. Belo Horizonte: Autêntica Editora, 2013.

ESPOSITO, R. (2020). Tratados a todo custo. Acessado em 20/04/2020 e encontrado em https://medium.com/@paulbpreciado_ptbr/tratados-a-todo-custo-de-roberto-esposito-

5b74ab4cdacd

FOUCAULT, M. (1975). Vigiar e Punir. Tradução: Raquel Ramalhete. $42^{a}$ ed. Petrópolis, RJ: Vozes, 2014.

HAN, B.-C. (2020) "A emergência viral e o mundo de amanhã" In Sopa de Wuhan: Pensamiento contemporâneo em tiempos de pandemias. Ideia, direção de arte, desenho e edição Pablo Amadeo, Editorial ASPO (Aislamiento Social Preventivo y Obligatorio), 2020.

NANCY, J-L. (2020). A emergência viral e o mundo de amanhã. Acessado em 16/04/2020 e encontrado em https://medium.com/@rondnunes/exce\%C3\%A7\%C3\%A3o-viral-de-jean-luc-nancy96446a71e4c6

PETERSEN, L.R; GUBLER, D. J. (2015). “Zoonoses Virais”. DECKER INTELLECTUAL PROPERTIES INC. Acessado em 16/04/2020 e encontrado em http://www.medicinanet.com.br/conteudos/acp-medicine/6179/zoonoses_virais.htm

PRECIADO, P. B. (2020). “Aprendendo com o vírus” In Sopa de Wuhan: Pensamiento contemporâneo em tiempos de pandemias. Ideia, direção de arte, desenho e edição Pablo Amadeo, Editorial ASPO (Aislamiento Social Preventivo y Obligatorio), 2020.

TRUONG, N. (2020). “Giorgio Agamben en entrevista: 'La epidemia muestra que el estado de excepción se há vuelto la regla'”. Le Monde. Acessado em 16/04/2020 e encontrado em artilleriainmanente.noblogs.org/?p=1381\&fbclid=IwAROHN9kW6R79bryfpOAQSZhprzd2pOi3obgeKfCYoOIf JrCdd7KIEzuMekw

Artigo recebido em: 28 de maio de 2020

Artigo aceito em: 13 de julho de 2020 